\title{
Perbandingan Implementasi Smart City di Indonesia: Studi Kasus: Perbandingan Smart People di Kota Surabaya dan Kota Malang
}

\section{Dyah Ratna Pramesti}

Ilmu Pemerintahan, Faculty of Social and Political Science, Universitas Muhammadiyah Yogyakarta

dyah.ratnapramesti@gmail.com

\section{Aulia Nur Kasiwi}

Ilmu Pemerintahan, Faculty of Social and Political Science, Universitas Muhammadiyah Yogyakarta

aulianurkasiwi@gmail.com

\section{Eko Priyo Purnomo}

Department of Government Affairs and Administration, Jusuf Kalla School of Government, Universitas Muhammadiyah Yogyakarta eko@umy.ac.id

\author{
E-ISSN (2721-0642) \\ Recieved: \\ June 252020 \\ Revised: \\ July 172020 \\ Accepted: \\ July 222020 \\ Doi Number \\ 10.37950/ijd.v2i2.61
}

\begin{abstract}
This study focuses on the problem of smart people as an indicator of the success of smart cities in Surabaya and Malang. Smart people are one of the supporting dimensions of the creation of a smart city or what is called a Smart City (Zubizarreta, Seravalli, And, E Arrizabalaga, 2016). So that the factors that make a city smart, one of which is measured by the quality of its human resources; which includes the human development index which is measured by how the level of unemployment, poverty level, health problems, and also seen from the aspect of public knowledge in receiving information, disseminating information, related to the development of creativity carried out and also the inclusiveness of empowering activities carried out by several people. (Iyer, 2018). In addition, the activities that are encountered in the city of Surabaya in community activities, already have quite innovative and creative networks. Meanwhile, Malang City is still heading for the stage of good quality. There needs to be motivation and encouragement so that Malang City is able to follow in the footsteps of the development of smart people in the city of Surabaya.
\end{abstract}

Keywords: implementation, smart city, smart people 


\begin{abstract}
Abstrak
Penelitian ini berfokus pada masalah smart people sebagai indicator keberhasilan smart city di Kota Surabaya dan Kota Malang. Smart people merupakan salah satu dimensi pendukung dari terwujudnya kota pintar atau yang disebut dengan Smart City (Zubizarreta, Seravalli, And, \& Arrizabalaga, 2016). Sehingga faktor-faktor yang menjadikan sebuah kota dapat dikatakan pintar salah satunya diukur dari kualitas sumber daya manusianya; yang meliputi dari indeks pembangunan manusianya yang diukur dari bagaimana tingkat pengamgguran, tingkat kemiskinan, masalah kesehatan, dan juga dilihat dari aspek pengetahuan masyarakat di dalam menerima informasi, menyebarkan informasi, terkait dengan penumbuhan kratifitas yang dilakukan dan juga inklusivitas pemberdayaan kegiatan yang dilakukan oleh beberapa orang (Iyer, 2018). Selain itu, aktifitas yang ditemui di Kota Surabaya dalam kegiatan komunitasnya, sudah memiliki jaringan yang cukup inovatif dan juga kreatif. Sedangkan untuk di Kota Malang masih menuju tahapan kualitas yang baik. Perlu adanya motivasi dan dorongan supaya Kota Malang mampu mengikuti jejak perkembangan smart people yang ada di Kota Surabaya.
\end{abstract}

Kata kunci: implementasi, smart city, smart people

\title{
Pendahuluan
}

Smart city merupakan bagian dari tata kelola perkotaan dalam mewujudkan kota yang berinovasi menggunakan teknologi dan jaringan sebagai alat yang utama, untuk mendorong proses komunikasi yang dilakukan oleh pemerintah dan juga masyarakat. Smart city juga mampu mendorong sebuah pengaturan di sebuah kota menajdi lebih efektif dan efisien, dikarenakan dengan konsep yang terintegrasi langsung dengan menggunakan konsep ICT. Sehingga mampu memberikan efek yang signifikan terhadap laju pertumbuhan kota di sebuah kota. ICT (Information and Communication Technology) adalah sebuah rancangan yang berbasis teknologi dan komunikasi, Teknologi Informasi meliputi segala hal yang berkaitan dengan proses, penggunaan sebagai alat bantu, manipulasi, dan pengelolaan informasi (Rahim Muhammad, 2011).

Penerapan smart city di Indonesia, yang sudah lama berjalan dan sudah memberikan hasil yang baik selama 5 tahun belakangan adalah Kota Bandung dan Kota Surabaya. Dua kota ini merupakan pionir pembangunan smart city yang ada di Indonesia. Beragam penghargaan pun sudah diraih oleh kedua kota ini. Sehingga, di dalam implementasinya, Kota Surabaya dan Kotaa Bandung sudah memberikan kontribusi yang baik di pembangunan tata ruang kota dan manajemen kota yang sustainable. Menurut IEEE Smart Cities.org smart city memiliki karakteristik, diantaranya adalah ekonomi pintar (smart economy), mobilitas cerdas, lingkungan cerdas (smart environment), orang pintar (smart people), hidup cerdas (smart living), pemerintahan cerdas (smart government).

Tentunya, di dalam membangun sebuah kota, tidak semua komponen tersebut terpenuhi. Oleh sebab itu, dari beberapa komponen karakteristik tersebut, penulis ingin 
melihat bagaimana satu karakteristik dari 6 karakteristik tersebut dapat di implementasikan di Kota Surabaya dan Kota Malang. Apakah dua kota kota ini sudah menjadi kota yang pintar dengan sumber daya manusianya, yang mana, penulis berasumsi bahwa, sumber daya manusia (smart people) sangatlah menentukan laju perkembangan smart city dengan menggunakan ICT sebagai masterplan yang digunakan. Sehingga dalam hal ini, kontribusi apa saja yang diberikan oleh Kota Surabaya dan Kota Malang di dalam mengembangkan atau memajukan smart city melalui SDMnya atau (smart people).

Potensi utama dan pertama kali di kembangkan oleh Kota Surabaya adalah penguatan Smart Governance. Pemerintah Kota Surabaya menguatkan dimensi smart governance dengan menguatkan pengurusan layanan publik secara online, yang dapat di akses secara publik. Selain itu, Kota Surabaya juga di dukung oleh cara kerja sistem pemerintahan dalam penyajian informasi terkait dengan penyusunan kebijakan pemerintahan yang transparan. Masyarakat di berikan ruang untuk ikut serta di dalam kebijakan yang diambil melalui ide, saran, dan kritik yang dilakukan secara online. Pemerintah Kota Surabaya juga di dukung oleh elemen infra struktur dalam menunjang smart governance, yaitu penyediaan wifi coverage dimana sebuah kota mampu menyediakan akses internet wireless (Wido Nurul, 2018).

Pemerintah Kota Surabaya melalui smart governance mampu menunjang dan mengedukasi masyarakat Kota Surabaya untuk build management system to smart city. Sehingga langkah utama Pemerintah Kota Surabaya di dalam membangun smart city ialah menggalakkan Pemerintah Kotanya, yang kemudian dapat dikembangkan lagi ke masyarakat melalui pelayanan yang diberikan dengan basis teknologi. Sehingga hal ini memperkuat posisi pemerintah Kota Surabaya untuk membangun sebuah kota dengan menggunakan konsep smart city. Penggunaan sistem teknologi juga mampu mencerdaskan penduduk kota yang notabene masyarakatnya terdapat berbagai jenis masyarakat. Ada yang sudah sadar teknologi da nada yang belum. Sehingga, pada awal pembangunan konsep smart city di Kota Surabaya, Pemerintah Kota lebih menggalakkkan pada dimensi pemerintahannnya. Karena pemerintahan menjadi pionir pembangunan yang utama di sebuah kota (Enceng, And, \& Hidayat, 2016).

Oleh sebab itu, di dalam pembangunan sebuah kota dengan menggunakan konsep smart city merupakan salah satu cara yang digunakan oleh Pemerintah Kota Surabaya untuk memberikan stimulus program kepada masyarakat supaya mampu bersinergi memberikan pengembangan sumber daya manusianya menuju (smart people) atau dapat dikatakan masyarakat pintar. Tidak hanya pintar tapi mampu memanfaatkan teknologi dengan baik. Paling tidak Kota Surabaya memberikan langkah atau first step beyond smart people. Selain itu, hal yang dapat dikaji dari smart people adalah bagaimana manajemen skills yang digunakan oleh masyarakatnya. Sehingga mampu memberikan kontribusi nyata di dalam perwujudan dimensi smart people yang ada di Kota Surabaya. Di dalam sebuah kota yang menggunakan konsep smart city, dimensi smart people sangatlah mempengaruhi laju perkembangan sebuah kota.

Pembangunan tata kelola kota dalam hal ini sesuai dengan perkembangan konsep kota pintar dan juga masyarakat atau orang yang pintar pula. Terdapat beberapa indicator menuurt (Nuzir, 2015) yang mengatakan bahwa untuk membentuk sebuah kota yang dihuni dapat dikatakan sebagai kota pintar, maka harus memiliki beberapa indikator diantaranya: memiliki hubungan sosial yang aktif dan terintegrasi dengan kegiatan yang prodduktif, kreatif dan inovatif. Menciptakan sebuah ide atau 
gagasan yang dapat diberdayakan oleh lingkungan sekitar dan membawa dampak positif terhadap keberlangsungan perkembangan indeks kualitas jaringan dan komunitas.

Selain itu, untuk menciptakan sebuah ide atau gagasan yang berwawasan lingkungan yang baik, maka menurut (Purnomo, Anand, And, \& Choi, 2017) mengatakan bahwa untuk membangun sebuah komitmen besar di dalam menjaga dan merawat sebuah lingkungan yang berkelanjutan, maka membutuhkan regulasi yang jelas antara pemerintah daerah, Pemerintah Pusat dan juga masyarakat lokal. Sehingga dapat mewujudkan suatu Kota dengan basis lingkungan yang berkelanjutan. Yang merupakan salah satu pendorong di bidang tata kelola kota yang berwawasan lingkungan.

\section{Kerangka Teori}

Menurut (Akhmad \& Nuzir, 2015) Konsep Smart City merujuk pada ke tiga dimensi, yaitu: Pertama, Dimensi teknologi, diperlukan Pembangunan kota yang digital dan terintegrasi dengan dukungan infrastruktur fisik, teknologi pintar, perangkat mobilitas tinggi dan jaringan komputer yang memadai.

Kedua, Dimensi Sumber Daya Manusia, diperlukan kreatifitas, pengetahuan, pendidikan dan pembelajaran sebagai pendorong utama terbentuknya kota yang cerdas, dimana permasalahan yang bersifat manual ditransformasi dengan pengetahuan ke model sistem digital melalui kratifitas dan disajikan dalam bentuk pembelajaran yang sepenuhnya dan terintegrasi dengan sistem yang baik.

Ketiga, Dimensi Institusional, diperlukan dukungan dari pemerintah dan kebijakan untuk pemerintahan sebagai dasar dari desain dan implementasi kota yang cerdas. Kebijakan Kebijakan tidak hanya mendukung tetapi juga berperan, dimana terbentuk hubungan antara lembaga pemerintah dan pihak non-pemerintah, dan sektor lainnya dalam membangun lingkungan administratif yang terintegrasi.

Menurut (Arnandy, Suryani, \& Ph, 2018) berdasarkan penelitian yang dihasilkan dalam jurnal ini, mengatakan bahwa kualifikasi indikator model yang dapat diukur di Kota Surabaya, terkait smart people, beberapa sub-model lainnya saling mempengaruhi, sub-model terdiri dari: Tingkat Kualifikasi, Partisipasi dalam Kehidupan Publik, Cosmopolitan Open-Mindedness, Model Persepsi Mendapat Pekerjaan Baru, Kreativitas. Berdasarkan hal tersebut, maka dapat ditarik kesimpulan bahwa model dalam simulasi tersebut, memiliki beberapa variabel yang dapat membantu meningkatkan tingkat Orang Cerdas di kota Surabaya, seperti sertifikasi perguruan tinggi, program kecakapan hidup, beasiswa, layanan publik yang transparan dan Pemberdayaan Pengusaha di pemerintah kota Surabaya.

Menurut Subekti Tia (2017) mengatakan bahwa konsep pengembangan smart city tidak hanya membeahas tentang penggunaan teknologi informasi dan komunikasi (TIK). Melainkan menekankan pada permasalahan yang menjadi masalah utama di kota (Purnomowati, And, \& Ismini, 2014). Sehingga menurut (Subekti Tia, 2017) sebuah kota bisa dikatakan sebagai kota cerdas jika memiliki kriteria sebagai berikut:

Pertama, Kota yang memiliki planning organitation yang baik di bidang ekonomi, sumberdaya manusianya, pemerintahan, mobilitas, lingkungan dan kehidupan yang di bangun berdasarkan perpaduan harmonis yang sejajar dengan satu sama lain. 
Kedua, Kota yang mampu terhubung baik dari segi infrastrukturnya termasuk jalan, jembatan, rel kereta api, bandara, pelabuhan, komunikasi, pemenuhan air listrik dan bahan bakar lain, serta dapat mengoptimalkan sumberdayanya dengan lebih baik.

Ketiga, Sebuah kota yang mampu mengolaborasikan antara infrastruktur fisik, infrastruktur Teknologi informasi, infrastruktur sosial, dan infrastruktur bisnid yang dapat di kolektifkan secara cerdas di dalam kota. Sehingga aktifitas yang ada saling terkoneksi satu sama lain.

Keempat, Sebuah kota yang dapat memanfaatkan secara efisien, berkelanjutan, adil dan layak huni terhadap kehidupan kota.

Kelima, Sebuah kota yang sudah menerapkan minimal teknologi smart computing termasuk administrasi kota, pendidikan, kesehatan, keselamatan umum, transportasi yang lebih cerdas dan saling terhubung.

Sementara menurut (Sucitawathi, Joniarta, And, \& Dewi, 2018) dengan adanya teknologi, maka akan memudahkan suatu kota untuk membangun sebuah perencanaan yang lebih efektif dan berkelanjutan. Seperti halnya sebagai berikut: Distribusi informasi yang di transfer maupun yang diterima mudah di akses. Menurunkan biaya transaksi, yang bermula harus menggunakan beberapa alat yang sifatnya materiil yang membutuhkan banyak biaya. Adanya beberapa bentuk atau konsep perdagangan bisnis yang lebih menarik dan dapat menarik pasar lebih besar daripada sebelum adanya teknologi informasi. Memudahkan di dalam mengakses informasi yang dibutuhkan secara umum terutama kebutuhan public di suatu kota. Menciptakan ruang yang lebih luas dan besar, terutama di bidang perdagangan dan pengembangan program wisata.

\section{Metode Penelitian}

Metode penelitian ini menggunakan metode deskriptif dengan teknik pengumpulan data yang memanfaatkan data-data sekunder melalui kajian pustaka. Sedangkan analisis data menggunakan content analysis, yaitu menelaah atau mengkaji secara lebih dalam, secara kritis terhadap data-data yang diperoleh oleh penulis, yaitu menganalisis dan mengkaji secara kritis dan mendalam tentang perbandingan smart people di Kota Malang dan Kota Surabaya. Menyimpulkan serta memberi rekomendasi atau saran-saran yang diperlukan. (Purnomo, Anand, \& Choi, 2017)

\section{Hasil dan Diskusi}

\section{Karakteristik Smart People di Kota Malang dan Surabaya}

\section{a. Kota Surabaya}

Menurut (Paramasatya, And, \& Rahmawati, 2017) ditemukan bahwa di Surabaya terdapat 2 kawasan yang menarik perhatian di dalam pengembangan konsep perkotaan melalui Smart City. Sehingga dalam penelitian tersebut dikatakan bahwa, Kampung Margo Rukun dan juga Kampung Lawas memiliki kontribusi yang cukup signifikan di dalam pengembangan desa menuju partisipasi Smart City. Mengapa demikian, data menuliskan bahwa masyarakat di Kampung Margo Rukun setidaknya mampu mengelola dan berkontribusi di bidang ekonomi yaitu, menciptakan lingkungan yang sadar teknologi, penggunaan internet, tersedianya sarana dan prasarana, tingkat pendidikan, beberapa kegiatan dan perkumpulan anak muda membangun kampung, dan masyarakat Kampung Margo Rukun juga aktif di dalam aplikasi pelayanan yang diberikan oleh pemerintah. Sehingga terjalin suatu interaksi/hubungan atau timbal baik antara pemerintah dan juga masyarakat. 
Masyarakat Kampung Lawas juga merupakan salah satu kampung yang memiliki aktifitas yang baik di dalam kegiatan industri dan pengembangan usahausaha kecil menengah. Dalam hal ini kegiatan yang dilakukan oleh masyarakat Kampung Lawas diantaranya; masyarakat di Kampung Lawas ini dapat mengakses informasi teknologi dengan baik. Memiliki pengetahuan tentang internet juga baik. Sehingga akses melalui media komunikasi dan informasi mudah di dapakan oleh masyarakat yang ada di kampung Lawas Mespati. Selain itu, kesadaran dan melek teknologi merupakan salah satu faktor pendukung di dalam mewujudkan pengembangan kota yang berkelanjutan dan berdaya saing atau kita menyebutnya dengan konsep Smart City atau kota pintar. Kemudian, menurut (Rahmawati et al., 2018) menyebutkan bahwa tingkat kualifikasi Smart People yang ditemui di Kampung Lawas Mespati ialah tingkat pendidikan yang baik, terdapat beberapa aktifitas yang produktif dalam kegiatan di Kampung Lawas Mespati. Aktifitas yang dijalankan di Kampung Lawas Mespati diantaranya mampu mentransfer komunikasi dengan baik terhadap lingkungan dan kegiatan yang memberikan mereka peluang untuk berinteraksi membangun aktifitas yang produktif.

\section{b. Kota Malang}

Menurut (Subekti Tia, 2017) urgensi penerapan Smart City di Kota Malang dilatarbelakangi oleh masalah-masalah perkotaan yang umum dihadapi oleh kota-kota besar di Indonesia pada umumnya. Seperti permasalahan kemacetan, lingkungan dan juga masalah ekonomi terutama pengangguran dan penyediaan lapangan pekerjaan. Adapun urgensi pokok permasalahan yang ditemukan antara lain; kepadatan bangunan yang semakin bertambah. Beserta dampaknya ialah berpotensi terjadinya penyempitan, penyumbatan serta tidak maksismalnya saluran air/drainase. Ditambah lagi kepadatan penduduk yang semakin bertambah. Menurut data kependudukan Kota Malang, jumlah penduduk di kota ini meningkat pada setiap tahunnya sekitar 1,58 persen. Tercatat pada 2015 penduduk Kota Malang berjumlah 881.794 Jiwa. Sementara pada akhir tahun 2016 tercatat sebanyak 887.443 jiwa. Sehingga dalam hal ini, tingkat pendudukan yang tinggi akan menghambat beberapa urgensi opembangunan tata kelola kota menurut (Hasanah, 2015).

Berdasarkan hasil penelitian yang dilakukan oleh (Wanto, 2014) menyebutkan bahwa pengembangan pembangunan atau penerapan Smart City di Kota Malang bermula pada penguatan sistem informasi yang dilakukan oleh pemerintah daerah. Sehingga dalam hal ini menurut (Purnomowati, And, \& Ismini, 2014) Pemerintah Kota Malang mewujudkan framework Smart City melalui program pariwisata. Dengan arah pembangunan jangka panjang, yang menitikberatkan pada pemanfaatan teknologi informasi dalam meningkatkan kualitas pelayanan pada masyarakat. Dengan melalui jaringan penyediaan sarana dan prasarana transportasi dan infrastruktur yang memadai serta pemberdayaan masyarakat. Dalam hal ini bertujuan untuk memantik masyarakat Kota Malang di dalam berkontribusi bersama Pemerintah Kota Malang untuk mewujudkan kota pintar. Jenis kualitas yang dapat kita lihat jika dilihat dari salah satu komponen Smart People maka dapat dikatan bahwa pengembangan smart people di Kota Malang menitik beratkan pada jaringan pemerintah melalui masyarakat dengan mendayagunakan pariwisata sebagai media untuk menyampaikan suatu program yang berkelanjutan dan berdaya saing. 


\section{Pengaruh Smart People terhadap keberhasilan Smart City di Kota Malang dan Surabaya}

\section{a. Kota Surabaya}

Pengembangan konsep kota pintar di sebuah kota akan berjalan seiring dengan kualitas sumber daya manusianya. Apabila sebuah sistem atau konsep yang diciptakan sudah bagus dan sesui dengan kondisi wilayah di sebuah kota, tetapi kualitas sumber daya manusianya rendah maka suatu sistem atau konsep hanyalah sebuah platform belaka. Untuk itu menurut (Prasetiyo Wibowo, 2013) pengembangan Kampung Hijau yang ada di Kampung Margorukun Surabaya dapat berjalan dengan baik. Dengan memiliki beberapa alternative kegiatan yang dilakukan yaitu; kegiatan peduli lingkungan, meliputi; kerja bakti rutin, penanaman dan perawatan tanaman, pemilahan sampah, perajangan sampah, pembuatan pupuk kompos, penataan tanaman bermain, arisan kader PKK, pembuatan tim yel-yel dan ada juga pengadaan bank sampah. Dalam hal ini strategi yang dilakukan oleh Kampung Margorukun, antara lain; keteladan dari orangtua dan kader peduli lingkungan Margorukun, penanaman kedisiplinan dengan mengikutsertakan anak dalam kegiatan peduli lingkungan di rumah dan masyarakat, kegiatan tanggung jawab melalui tugas membersihkan rumah dan integrasi dan internalisasi karakter peduli lingkungan.

Menurut (Silas, And, \& Ernawati, 2011) pengembangan smart people yang ada di Kota Surabaya menekankan pada prinsip lingkungan yang berdaya manfaat dan juga pengembangan karakteristik manusianya yang memiliki semangat yang kuat di dalam pengembangan ekologi di Kampung Surabaya. Data menunjukkan bahwa keberhasilan beberapa kampung kreatif yang ada di Surabaya memiliki peran aktif di dalam pembangunan kualitas hidup masyarakatnya. Sehingga melalui pengembanganpengembangan yang sederhana di mulai dari hal kecil, dapat memberikan pengaruh yang signifikan di dalam pengembangan smart people yang ada di Kota Surabaya. Menurut (Affandi, Setijadi, Kusrahardjo, And, \& Suprajitno, 2016) menyebutkan partisipasi mahasiswa yang ada di ITS (Institut Teknologi Surabaya) di dalam membangun kota pintar di Surabaya memberikan daftar kualitas baik. Diantaranya yang dilakukan adalah melalui penciptaan sebuah aplikasi dan program yang digunakan di dalam pengembangan jaringan komunikasi dan juga sistem informasi bagi masyarakat. Pengembangan yang dilakukan ialah SIEC-ITS (Smart-city $\mathcal{E}$ Intellegent Exellent Center ITS) yaitu, sebuah research group yang artinya merupakan kumpulan dari beberapa peneliti dan penggiat penerapan TIK dalam platform Smart-city dan pencarian solusi cerdas (Intellegent) dari permasalahan-permasalahan di masyarakat. Para penliti yang tergabung di dalam research group memiliki berbagai jenis bidang atau fokus pada beberapa jenis penelitian, diantaranya; dari Laboratorium Jaringan Telekomunikasi, Laboratorium Telekomunikasi Multimedia, Laboratorium Sipil Transport dan termasuk pemanfaatan Laboratorium Informatika saat uji coba security. Para peneliti yang tergabung tertarik masuk ke bidang smart city merupakan salah satu jargon jaringan nasional yang dapat digunakan sebagai pengambangan TIK di suatu kota dan juga pemanfaataannya. Dengan adanya SIEC-ITS harapannya mampu membawa roadmap smart city menuju kota yang berkelanjutan.

Selain itu, inovasi yang dilakukan jika dilihat dari pemanfaatan smart people adalah Kampung Literasi ITS yang merupakan sebuah program dari anak ITS untuk menggalakkan literasi dengan menggalakkan Taman Baca Masyarakat atau disebut dengan TBM, (Nuswantara, Bhawika, And, \& Qomariyah, 2018). Pengembangan budaya literasi seperti TBM mampu memberikan manfaat yang efektif jika dilakukan 
dengan cara memberdayakan fungsi kelompok literasi yang disesain supaya anak bisa dan terbiasa dengan aktifitas membaca berbagai jenis tekst. Sehingga dalam hal ini program TBM memberikan dampak positif di dalam modal sosial anggota TBM terkait (Pengembangan diri, Motivasi dan Apresiai) memlalui mading (majalah dinding) dan beberapa karya tulis lain yang dapat dilakukan oleh masyarakat di Kampung Baca tesebut.

Strategi lain di dalam kegiatan smart people di Surabaya salah satunya dengan melibatkan kalangan pemuda dengan komunitas pemuda yang menjadi duta wisata. Sehingga dalam perkembangan smart people yang ada di Kota Surabaya melibatkan beberapa pemberdayaan dan kegiatan, salah satunya dengan pengenalan promosi melalui Cak dan Ning Surabaya yang merupakan Duta Wisata Kota Surabaya dalam membantu Kota Surabaya dalam mewujudkan kota wista.

\section{b. Kota Malang}

Berdasarakan penelitian yang dilakukan oleh (Putro, 2019) menyatakan bahwa konsep pengatan smart people di Kota Malang menggunakan beberapa skala prioritas supaya menuju smart people yang berdaya guna. Dengan melakukan penguatan kinerja untuk mengakomodir pendidikan formal dan informal. Penguatan aplikasi konsultasi belajar (KBS) untuk formal dan informal. Aplikasi educating planning yang dilakukan oleh orang tua dalam merencanakan pendidikan anak. Portal informasi pendidikan yang dapat di akses oleh semua siswa. Penguatan jaringan provider dan internet. Peningkatan inovasi dan kreatifitas masyarakat di berbagai bidang, seperti pembentukan smart community. Aplikasi smart community dan kalander event.

Menuurut (Sulhan, And, \& Sasongko, 2017) pemberdayaan masyarakat untuk mewujudkan masyarakat yang pintar, maka perlu diakan beberapa tahapan pengenalan, diantaranya melakukan sosialisasi program-program yang dilakukan oleh pemerintah untuk mengikutsertakan masyarakat di dalam pengembangan kota yang cerdas, tidak hanya kotanya tetapi juga masyarakatnya. Seperti yang disebutkan di dalam penelitian oleh (Wanto, 2014) komitmen Pemerintah Kota Malang di dalam mewujudkan kota yang berbasis kota pintar, melakukan beberapa strategi; diantaranya, membangun terlebih dahulu Political Environtment, membangun teknologi yang mendukung terselenggaranya proses pelayanan publik. Membangun strategi penyelenggaraan untuk anggaran yang di butuhkan, kemudian yang terakhir adalah strategi partisipasi seluruh stakeholder dalam mendukung terlaksananya program.

Dalam hal ini, aktifitas masyarakat, komunitas dan pegiat lainnya yang ada di Kota Malang memiliki tingkatan yang jauh lebih rendah daripada yang ada di Kota Surabaya. Karena, salah satunya disebabkan oleh penerapan dari Pemerintah Kota sendiri lebih dulu Kota Surabaya dan terus berlangsung hingga saat ini. Sehingga proses kurun waktu yang lama dan konsistensi di dalam pengembangan ilmu teknologi sangat berpengaruh di dalam eksistensi pemerintah mewujudkan kota pintar dan masyarakat kota yang pintar (Aeni, 2017).

\section{Kesimpulan}

Berdasarkan hasil analisis yang dilakukan oleh penulis, penulis menitik-beratkan pada beberapa poin penting terkait karakteristik pembangunan smart people di Kota Surabaya dan Kota Malang. Pada dasarnya penerapan smart people di Kota Surabaya sudah memiliki kontestasi indeks pengengembangan sumber daya manusianya. Ditandai dengan berdirinya beberapa komunitas-komunitas baik dari lingkungan 
kampus maupun dari organisasi masyarakat dan perkumpulan masyarakat yang ada di Kampung Surabaya. Sehingga faktor-faktor inilah yang kemudian menjadi sebuah sasaran dan berubah menjadi platform pembangunan smart city di Kota Surabaya. Kemudian untuk Kota Malang, sumber daya manusianya di dalam melakukan pengembangan perluasan jaringan hubungan antar komunitas memiliki sebuah motivasi untuk menuju ke arah pergerakan menuju kualitas yang baik dan memiliki daya guna yang tinggi. Selain itu, faktor lain yang menjadikan konsep kota pintar berhasil; diantaranya dipengaruhi oleh mobilitas pergerakan aktifitas di segala aspek, mulai dari pergerakan organisasinya, kemasyarakatnya dan juga dari faktor sumber daya manusianya yang berlatang belakang pendidikan yang tinggi. Sehingga aspek itu dapat mendukung dan membantu pemerintah dalam hubungan yang vertikal dan dapat berupa hubungan yang horizontal. Hubungan horizontal yang terjadi di masyarakat dan pergerakannya masuk dalam aspek hubungan horizontal. Sehingga di dalam mewujudkan kota pintar, haruslah juga memiliki pergerakan di bidang sosial dan masyarakat.

\section{Tentang Penulis}

Dyah Ratna Pramesti adalah mahasiswi jurusan Ilmu Pemerintahan, Universitas Muhammadiyah Yogyakarta.

Aulia Nur Kasiwi adalah peneliti muda di bidang Asia Pacific Society for Public Affairs, Universitas Muhammadiyah Yogyakarta.

Eko Priyo Purnomo adalah dosen senior di Department of Government Affairs and Administration, the Jusuf Kalla School of Government, Universitas Muhammadiyah Yogyakarta.

\section{Ucapan Terimakasih}

Saya mengucapkan terimakasih kepada semua pihak yang telah membantu saya di dalam serangkaian proses penelitian. Khususnya kepada Bapak Eko Priyo Purnomo, selaku dosen pengampu mata kuliah tata kelola perkotaan, yang telah memberikan penjelasan terkait teori-teori tata kelola perkotaan dan juga kepada mentor saya Aulia Nur Kasiwi selaku asisten dosen, yang telah memberikan masukan, kritik, dan saran di dalam serangkaian proses penelitian.

\section{References}

Alkaf, And, \& Sutrisno. (2019). Smart surveillance. Jurnal Sosioteknologi, 2(April), $92-$ 102. https://doi.org/10.5614/sostek.itbj.2019.18.1.7

Akhmad,F. ,\& Nuzir. (2015). Smart People, Smart Mobility, (September), 2-6. https:// doi.org/10.13140/RG.2.1.3056.4324

Arnandy, D. A., \& Erma Suryani, S. T. (2018). Dynamic System Model Development for Strategic Planning Information Technology in the Framework of Developing Smart People and Smart Economy (Case Study in Surabaya). 
Aeni. (2017). Kontribusi Kampung Warna Jodipan Kota Malang Dalam Meningkatkan Pemberdayaan Ekonomi dan Pendidikan Sosial Masyarakat Menuju Smart City. (pp. 35-89).

Affandi, Setijadi, Kusrahardjo, And, \& Suprajitno. (2016). Inovasi SIEC-ITS dalam Implementasi Teknologi Informasi dan [Tele]Komunikasi Mendukung Framework Smart-city yang Berkelanjutan. In Conference on Innovation and Industrial Applications (CINIA 2016) (pp. 1-8). China.

April Insani, P. (2017). Mewujudkan Kota Responsif Melalui Smart City. PUBLISIA (Jurnal Ilmu Administrasi Publik), 2(Smart City), 25-31.

Bappenas. (2015). Pengembangan Kota Cerdas di Indonesia. In Kementrian PPN (Ed.), Pengembangan Kota Cerdas di Indonesia (pp. 5-45). Bandung: Bappenas.

Budiman, Darmawan, And, \& Kurniawati. (2013). Analisis dan Perancangan Sistem Social e-Learning untuk Mendukung Program Bandung Smart City. Jurnal Tugas Akhir, 2(1), 998.

Carolina, N., \& Alcantara, G. L. L. (2014). Development of a Smart City and its Adoption and Acceptance: the Case of New Songdo (*). Digiworld Economic Journal, 4(96), 113-128.

Enceng, And, \& Hidayat. (2016). Peningkatan Layanan Publik Melalui Smart Governance Dan Smart Mobility. Jurnal Administrasi Pembangunan, 4(2), 87-156.

Felasari, S., \& Roychansyah, M. S. (2019, October). Importance performance analysis for smart city implementation in Surabaya, Indonesia. In IOP Conference Series: Earth and Environmental Science (Vol. 340, No. 1, p. 012039). IOP Publishing.

Hasanah. (2015). Green City , Smart City , Compact City , Mega City. In Researchgate (pp. 3-19).

Iyer. (2018). Smart Cities, Connected Communities Data-Driven Decision Making in West Baltimore for Smart Technology Planning. Frances: Jacob France Institute.

Kshetri, N., Alcantara, L. L., \& Park, Y. (2014). Development of a smart city and its adoption and acceptance: the case of new songdo. Communications \& Strategies, (96), 113.

Monzon. (2015). Smart Cities Concept and Challenges. Nternational Conference on Smart Cities and Green ICT Systems (SMARTGREENS), Vol. 1 No.(Januari), 1-11.

Nuswantara, Bhawika, And, \& Qomariyah. (2018). Kampung Literasi ITS sebagai Model Pengembangan Literasi di TBM. Jurnal Pengabdian Kepada Masyarakat LPPM ITS, 2(2), 76-84.

Nuzir. (2015). Smart People, Smart Mobility. In Researchgate (September, pp. 5-15). -. https:/ / doi.org/10.13140/RG.2.1.3056.4324

Paramasatya, And, \& Rahmawati. (2017). Penentuan Variabel Berpengaruh Terhadap Pengembangan Kampung Cerdas dalam. Jurnal Teknik, 6(2), 434-437.

Pelayanan Publik Berbasis Konsep Smart City . Jurnal Administrasi Publik, 39-43.

Prasetiyo Wibowo, S. T. (2013). Strategi Pendidikan Karakter Peduli Lingkungan Melalui Program Kampung Hijau Di Kampung Margorukun Surabaya 303-315. 
Purnomowati, And, \& Ismini. (2014). Konsep Smart City dan Pengembangan Pariwisata. Jurnal JIBEKA, Vol. 8 No.(Februari), 65-71.

Purnomo, Anand, And, \& Choi. (2017). The complexity and consequences of the policy implementation dealing with sustainable ideas. Journal of Sustainable Forestry, 00(00), 1-16. https:// doi.org/10.1080/10549811.2017.1406373

Putro. (2019). Road Map Smart City di Kota Malang. Jurnal Pangripta, Vol. 1. No1.(Maret), 307-319.

Rahmat, A., Syadiah, N., \& Subur, B. (2016). Smart coastal city: sea pollution awareness for people in surabaya waterfront city. Procedia-Social and Behavioral Sciences, $227,770-777$.

Rahmawati, Sulistyarso, Ariastita, Yusuf, And, \& Paramasatya. (2018). Smart kampung for Surabaya smart city: Criteria redefined Smart kampung for Surabaya smart city: Criteria redefined. In Rahmawati (Ed.), IOP Conference Series: Earth and Environmental Science (pp. 1-7). Surabaya, Indonesia: Institut Teknologi Sepuluh Nopember.

Silas, J., \& Ernawati, R. (2013). Liveability of Settlements by People in the Kampung of Surabaya. In Proceedings of the 19th International CIB World Building Congress: Construction and Society, QUT, Brisbane (pp. 1-7).

Silas, And, \& Ernawati. (2011). Liveability of Settlements by People in the Kampung of Surabaya. Jurnal Ilmu Pemerintahan Dan Kebijakan Publik, 4-8.

Subekti Tia. (2017). Menguji Sistem E-Government Kota Malang Menuju Smart City. In Researchgate (pp. 18-30).

Sucitawathi, Joniarta, And, \& Dewi. (2018). Konsep “ Smart City " Dan Tata Kelola Pemerintahan Di Kota Denpasar. Jurnal Administrasi Publik, 3(1), 9-15.

Sulhan, And, \& Sasongko. (2017). Implementasi Kebijakan Program Penanggulangan Indonesia Pintar ( Studi Kasus di Kelurahan Kauman Kota Malang ). Jurnal Ilmu Sosial Dan Ilmu Politik, 6(1), 15-18.

Wanto. (2014). Strategi Pemerintah Kota Malang Dalam Meningkatkan Kualitas

Widodo. (2016). Pengembangan e-Government di Pemerintahan Daerah Dalam Rangka Mewujudkan Smart city (studi di Pemerintah Daerah Kota Malang). Jurnal Ilmiah Administrasi Publik, 2(4), 227-235.

Zubizarreta, Seravalli, And, \& Arrizabalaga. (2016). Smart City Concept: What It Is and What It Should Be. Journal Urban Planning Developement, 142(1), 1-8. https://doi.org/10.1061/(ASCE)UP 